\title{
Self-Rated Oral Health Status And Social And Health Determinants Among 35-65 Year-Old Persons In One Region In Myanmar: A Cross-Sectional Study
}

This article was published in the following Dove Press journal:

Clinical, Cosmetic and Investigational Dentistry

Isareethika Jayasvasti (D)

Khin Chaw Su Su Htun ${ }^{2}$

Karl Peltzer (D) ${ }^{3}$

'ASEAN Institute for Health Development, Mahidol University, Salaya, Thailand; ${ }^{2}$ Biomedical Science Department, University of Community Health, Magway, Myanmar; ${ }^{3}$ Deputy Vice Chancellor Research and Innovation Office, North West University, Potchefstroom, South Africa
Correspondence: Karl Peltzer Deputy Vice Chancellor Research and Innovation Office, North-West University, Potchefstroom Campus, II Hoffman Street, Potchefstroom 253I, South Africa

Email kfpeltzer@gmail.com
Background: Oral diseases may be a population health problem in Myanmar. Communitybased surveys may help in the selection of risk groups that may require priority attention. The study aimed to estimate the prevalence and correlates of self-rated oral health (SROH) status in an adult community sample in Myanmar.

Methods: The study design was a cross-sectional household survey in the Magway region Myanmar. In all, 633 persons aged 35 to 65 years, responded to questions on the oral health status, general health status, oral health knowledge and behaviour and socio-demographic information.

Results: Overall, $13.6 \%$ of participants reported poor $\mathrm{SROH}$, and $78.5 \%$ average or poor $\mathrm{SROH}$. In adjusted logistic regression analysis, oral conditions (tooth loss, cavities, bleeding gums, and teeth that are sensitive to heat or cold), better oral health knowledge, dental care attendance, and skipping breakfast were associated with poor SROH.

Conclusion: A high proportion of poor or average SROH status was found and several associated variables were found that can facilitate in guiding oral health care programming in Myanmar.

Keywords: self-rated oral health status, oral conditions, oral health behaviour, general health status, general health behaviour, adults, Myanmar

\section{Background}

"Oral diseases are major public health problems worldwide and poor oral health has a profound effect on general health and quality of life."1 Generally, there has been an increase in focussing on health care that is patient-centered, and in this context, it is important to include both physical and social dimensions of health as well as oral health or self-rated oral health (SROH) status. ${ }^{1}$ One's SROH status may influence the utilization of dental care, and thus, knowing the determinants of SROH status can help in improving dental health care services. ${ }^{2}$ Studies found that $\mathrm{SROH}$ status is significantly related to the oral health status examined clinically. ${ }^{3}$ There is scarce information on the prevalence and correlates of SROH among community-dwelling adults in Southeast Asian countries, including Myanmar. ${ }^{4}$ For example, in a survey among university students in five Southeast Asian countries, 27.7\% of students (in Myanmar 28.8\%) reported "to have sometimes, most of the time or always having toothache in the past 12 months". The prevalence and correlates of poor or good SROH status depend on their sociocultural context, which may differ in Myanmar compared to countries in other world regions. ${ }^{1,2}$ 
The two most common oral diseases in Myanmar include dental caries and periodontal diseases, and oral cancer has been increasing. " 5 "The high proportion of untreated caries showed lack of people's awareness regarding oral problems, low utilisation of oral health care services, and unmet needs. $^{5}$

Different national and regional studies on the prevalence of SROH status are described in Table 1, e.g., in Australia 17\% "fair"or "poor", 6 in Brazil 44.7\% "dissatisfied"or "very dissatisfied", 7 in Kenya $13.7 \%$ "poor" or "very poor", 8 in Nigeria 9\% "poor'or "very poor", 9 in Qatar 5.9\% "poor" or "very poor", 10 in South Africa 23.7\% "neither good nor bad" or "poor" or "very poor", 11 in Sweden $3.2 \%$ "poor", 12 in Turkey 65\% "poor", 13 and in USA 11.9\% "poor". 14 (see Table 1).

Sociodemographic factors associated with poor $\mathrm{SROH}$ status may include younger ${ }^{13}$ or older age, ${ }^{6,15}$ male or female sex $^{6,11,15,16}$ and low socioeconomic position. ${ }^{6,7,11,12,16,17}$ Oral conditions, such as fewer teeth, ${ }^{18}$ bleeding gum, tooth sensitivity, bad breath, ${ }^{11}$ dental caries, ${ }^{19}$ and toothache, ${ }^{20,21}$ have been found to increase the odds for poor $\mathrm{SROH}$ include. Several general health status factors, such as chronic conditions, ${ }^{17}$ overweight, ${ }^{4}$ obesity, ${ }^{22}$ psychological distress, ${ }^{23}$ depression $^{17,24}$ and sleep disturbance, ${ }^{25}$ have also shown to be associated with poor SROH.

Oral health-risk knowledge and behaviour factors for poor SROH include low knowledge or literacy on oral health, ${ }^{26,27}$ inadequate tooth cleaning, ${ }^{11}$ poor oral hygiene behaviours, ${ }^{15}$ and no, low or frequent dental attendance. $7,11,13,17,24,29$ Several general health-risk behaviours, such as current smoking, ${ }^{6,11,17,30}$ problem drinking, ${ }^{6,17}$ poor diets, ${ }^{30}$ and food avoidance (e.g., fruits and raw vegetables), ${ }^{31}$ have been found associated with poor $\mathrm{SROH}$ status.

The study aimed to estimate the prevalence and correlates of $\mathrm{SROH}$ status and associated factors in an adult community sample in Myanmar.

\section{Methods}

\section{Sample And Procedure}

Using a cross-sectional study design, 633 participants aged 35 to 65 years selected through multi-stage cluster random sampling from an "urban area of Magway Township" in 2015 were included in the investigation; more details have been described elsewhere. ${ }^{32}$

The questionnaire used was translated from English to Myanmar using standard research procedures and piloted on a sample of 25 adults not forming part of the final sample to check validity and reliability. ${ }^{32}$ The study was approved the Committee for Research Ethics (Social Sciences), Mahidol University (MU-SSIRB No.: 2016/ 1421204), which is in full compliance with the 'International Guidelines of Human Research Protection such as Declaration of Helsinki, The Belmont Report, and CIOMS Guidelines', and the Committee of University of Community Health (Magway), Myanmar. ${ }^{32}$ ss

Informed written consent was obtained from all participants prior to the study.

\section{Measures}

The questionnaire consisted of socio-demographic data (sex, age, household income and education), oral conditions, general health status, oral health knowledge and behaviour, general health behaviour and SROH status.

SROH was assessed with two questions, 1) "How would you describe the state of your teeth, and 2) gums?" Responses ranged from " $1=$ excellent to $6=$ very poor" 33 (Cronbach alpha 0.80). "Poor SROH status was classified as having poor or very poor status of teeth and/or gums, and good oral health as having average to excellent status of teeth and/or gums". 32

\section{Oral Conditions}

Loss of teeth was measured with the item, "How many natural teeth do you have? (Response options: $1=$ no natural teeth, 2=1-9 teeth, 10-19 teeth, and 20 teeth or more)". 33 "Responses were classified into having 0-19 teeth and 20 or more teeth.",32

Dentures. "Do you have any removable dentures?" (Yes, No). ${ }^{33}$

Having cavities was defined as " $1=$ having one or more cavities and $0=$ having no cavities," 32 based on the question "How many cavities have you had in your permanent teeth?"33

Physical symptoms were asked with the question, "Within the previous month, did you experience any of the following common oral conditions? 1) bleeding gums when brushing, 2) teeth sensitive to heat or cold, 3) bad breath, or 4) none."11

\section{General Self-Reported Health Status}

Chronic medical conditions were measured with the variables,

Have you been diagnosed (by a doctor or other health worker) with ... ? (Asthma, Arthritis, Diabetes or high blood sugar, High cholesterol/high blood lipids, Heart 


\begin{tabular}{|c|c|c|c|c|c|c|c|c|c|}
\hline 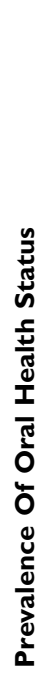 & 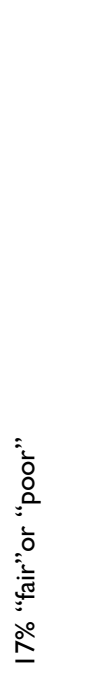 & 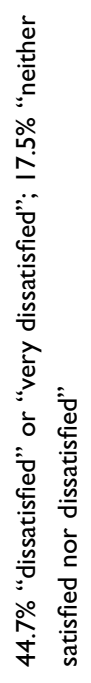 & 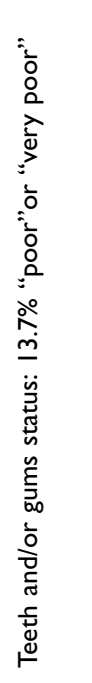 & 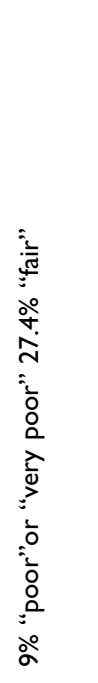 & 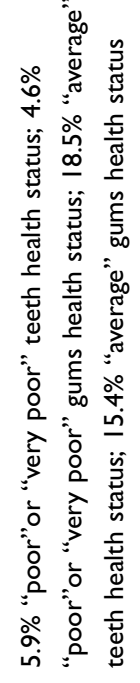 & 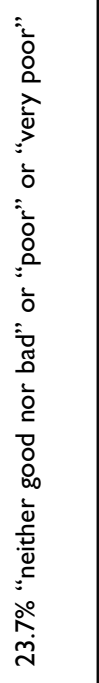 & 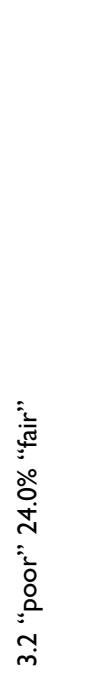 & 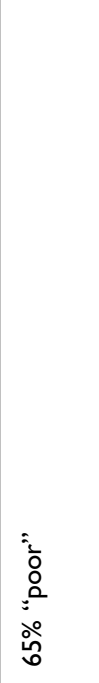 & 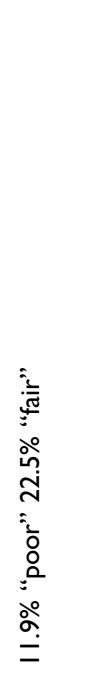 \\
\hline 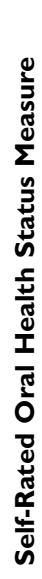 & 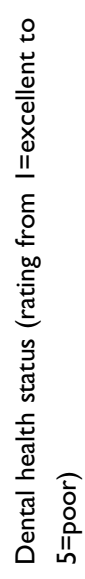 & 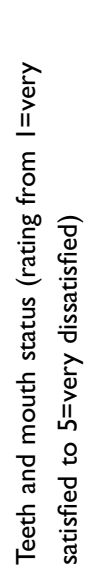 & 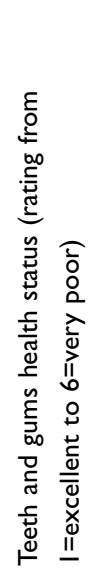 & 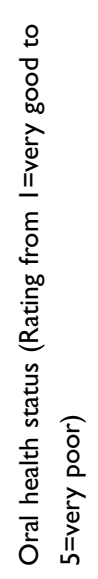 & 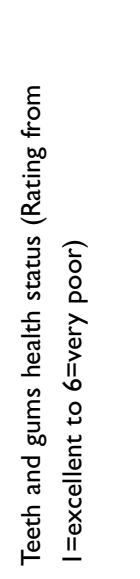 & 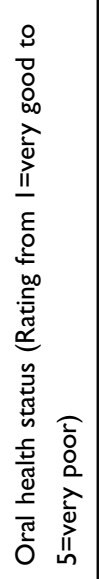 & 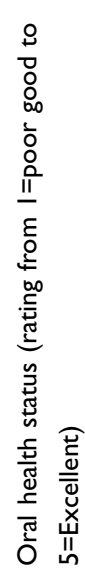 & 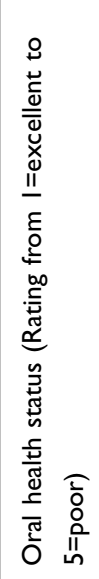 & 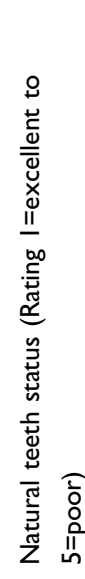 \\
\hline $\begin{array}{l}\frac{0}{\circ} \\
\frac{\mathrm{E}}{5} \\
\text { जी }\end{array}$ & 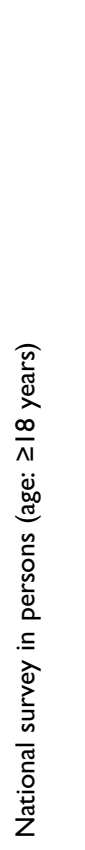 & 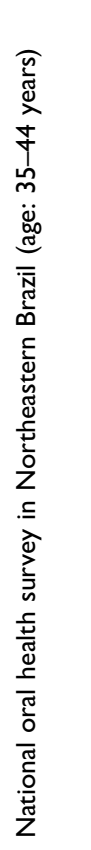 & 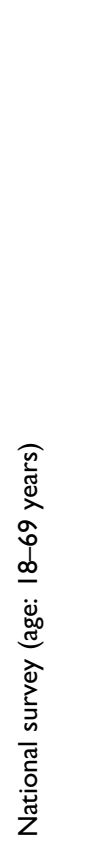 & 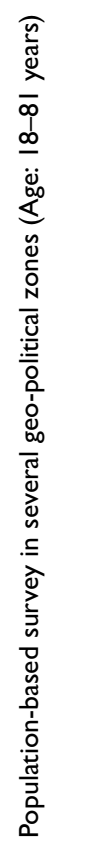 & 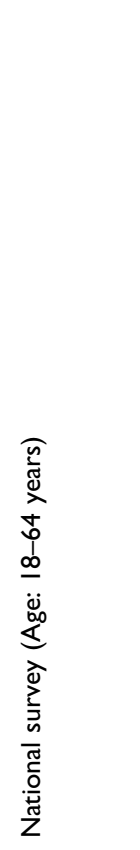 & 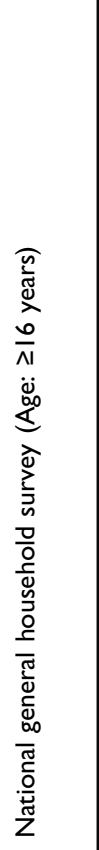 & 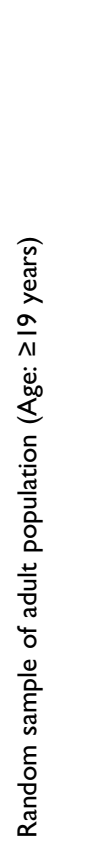 & 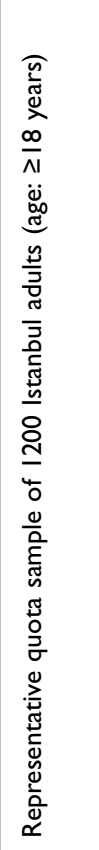 & 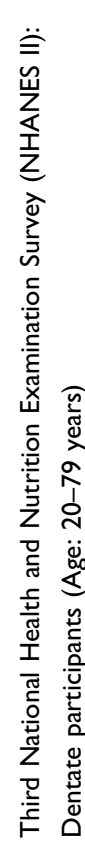 \\
\hline نे & 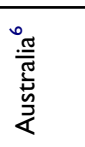 & $\begin{array}{l}\overline{\bar{N}} \\
\bar{\Phi} \\
\bar{D}\end{array}$ & 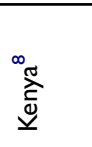 & 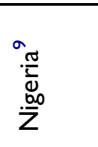 & 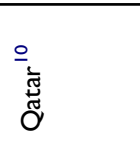 & 点 & 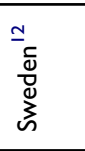 & 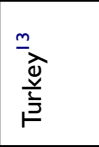 & 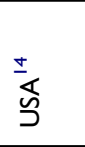 \\
\hline
\end{tabular}


disease, Stroke, Kidney disease, and Cancer). Responses were classified into $1=$ having one or more chronic conditions and $0=$ having none. ${ }^{32}$

Body mass index (BMI) based on self-reported weight and height was "classified according to Asian criteria: normal weight ( 18.5 to $<23.0 \mathrm{~kg} / \mathrm{m}^{2}$ ), overweight ( 23.0 to $<25.0$ $\mathrm{kg} / \mathrm{m}^{2}$ ) and $25+\mathrm{kg} / \mathrm{m}^{2}$ as obese." 34

The "Patient Health Questionnare-9 (PHQ-9)" was used to assess depression. ${ }^{35}$

It has demonstrated high sensitivity (0.84) and specificity (0.77) in a validation study in Thailand (culturally similar to Myanmar), using a cut-off score of nine or more as indicative for major depression symptoms. (Cronbach alpha 0.84$)^{32,36}$

Sleep problems were defined as moderate, severe or extreme in response to the question,

Overall in the last 30 days, how much of a problem did you have with sleeping, such as falling asleep, waking up frequently during the night, or waking up too early in the morning? Response options ranged from $0=$ none, $1=$ mild, $2=$ moderate, $3=$ severe, and $4=$ extreme/cannot do. ${ }^{37}$

Oral health knowledge was measured with eight items from an oral health knowledge or literacy questionnaire. ${ }^{38}$ Items asked about prevention of tooth decay, permanent teeth, bleeding after brushing or flossing, management of pain and swelling in the mouth, link between oral health and general health. Response options were heterogeneous multiple-choice formats. Correct responses of the eight oral health knowledge items were summed, with scores from 0 to 3 indicating low and 4-8 high oral health knowledge.

Oral health behaviours were measured with four questions: ${ }^{33}$

1) "How often do you clean your teeth?" (Responses: "1=never to 7 twice or more a day"); 2) "Do you use toothpaste containing fluoride?"("Yes or No"); 3) "How long has it been since you last saw a dentist?" (Responses: " $1=$ less than 6 months to $6=$ never received dental care"); 4) “Consumption of soft drinks?"(Responses: " $1=$ more than once a day to $6=$ never").

\section{General Health Behaviour}

Current smokers were defined as daily and/or not daily smokers, based on the question, "Do you currently smoke any tobacco products (such as cigarettes, bidis, cigars, pipes, betel)?"33
Current smokeless tobacco use was defined as daily and/or not daily, based on the question, "Do you currently use any smokeless tobacco products (such as snuff or chewing tobacco)?"33

Problem drinking was measured with the "Alcohol Use Disorder Identification Test (AUDIT)-C". ${ }^{39}$ (Cronbach alpha 0.86).

Fruit and vegetable consumption were assessed with the questions,

How many servings of fruit do you eat on a typical day? [One standard serving $=80$ grams, or $6-8$ pieces of ripe papaya, water melon or pineapple, 1 banana, 1 tangerine, 4 rambutans, $1 / 2$ cup of no-added-sugar processed fruit, 1/2 cup of canned fruit or $1 / 2$ cup of $100 \%$ fruit juice]

and

How many servings of vegetables do you eat on a typical day. [One standard serving $=80$ grams or $1 / 2$ cup of cooked leafy vegetables, 1 cup of raw green leafy vegetables, $1 / 2$ cup of tomato, carrot, pumpkin, cabbage, beans or white onion, or $1 / 2$ cup of $100 \%$ vegetable juice]

Less than five servings a day was defined as insufficient. ${ }^{33,40}$

Breakfast consumption was measured with the variable, "How often do you eat breakfast?" Response options were $1=$ Almost every day, $2=$ =sometimes, $3=$ rarely or never. Less than "almost every day" was defined as skipping breakfast.

\section{Statistical Analysis}

All statistical analyses were conducted with "IBM SPSS (version 24.0) (Chicago, IL, USA)". Logistic regression analysis was applied to estimate the association between socio-demographic variables, oral conditions, general health status, oral health knowledge and behaviour, general health behaviour and poor SROH. The selection of the determinants of $\mathrm{SROH}$ was based on literature review. ${ }^{4,6,7,11-13,15-25}$ To avoid Type 1 error $\mathrm{p}$ was set at $<0.01$ as significant in the multivariable model. "Variance inflation factor (VIF) and tolerance values" found that multicollinearity was not a cause of concern in the multivariable analysis.

\section{Results}

Sample Characteristics And Bivariate Analysis Between Individual Risk Factors And Poor SROH

The study sample consisted of 633 adults aged 35 to 65 years (mean age $=45.0$ years, $\mathrm{SD}=8.6$ ), and $55.0 \%$ were 
male and $45.0 \%$ women. The study response rate was $98 \%$ of the 646 targeted household participants, 13 had declined the interview.

The proportion of participants who had 0-19 natural teeth was $11.1 \%$, one or more cavity $48.2 \%$, removable dentures $4.6 \%$, experienced pain in the teeth or mouth $27.2 \%$, bleeding gums when brushing $13.6 \%$, and had teeth sensitive to heat or cold $17.5 \%$. Almost one in five $(17.9 \%)$ of the respondents had one or more chronic conditions, $27.2 \%$ overweight or obesity, $3.9 \%$ depressive symptoms, and $11.2 \%$ sleep problems.

In relation to oral health knowledge and behaviour, $52.3 \%$ scored 4-8 (high) on oral health knowledge, $58.0 \%$ cleaned their teeth $\geq$ twice per day, $84.2 \%$ had used "toothpaste with fluoride", $42.2 \%$ had soft drinks zonce per day and $12.3 \%$ had consulted a dentist in the past 12 months. Overall, $13.6 \%$ of participants reported poor $\mathrm{SROH}$, and $78.5 \%$ average or poor $\mathrm{SROH}$.

In bivariate analysis, having oral conditions (tooth loss, cavities, dentures, pain in teeth or mouth, bleeding gums, and teeth that are sensitive to heat or cold), poorer general health status (having chronic conditions, short and/or long sleep), better oral health knowledge, poorer tooth cleaning habits, dental care attendance, general health-risk behaviour (smokeless tobacco use, and skipping breakfast) and lower education were associated with poor $\mathrm{SROH}$ (see Table 2).

\section{Descriptives Of Oral Health Status By Gender And Age Group}

Overall, $29.1 \%$ of participants rated the state of their teeth as good, very good or excellent, $58.0 \%$ as average, and $12.9 \%$ as poor or very poor, likewise, $34.9 \%$ of participants rated the state of their gums as good, very good or excellent, $56.9 \%$ as average, and $7.1 \%$ as poor or very poor. Women rated the state of their teeth and gums better than men did, and the older age group (50-65 years) rated the state of their teeth better than the younger age group (35-49 years) (see Table 3 ).

\section{Associations With Poor Self-Rated Oral Health}

In adjusted logistic regression analysis, oral conditions (tooth loss, cavities, bleeding gums, and teeth that are sensitive to heat or cold), better oral health knowledge, dental care attendance, and skipping breakfast were associated with poor SROH (see Table 4).

\section{Discussion}

High reports of poor (13.6\%) and average or poor (78.5\%) SROH were found in this study, which seem to be higher than in several previous studies in different countries. ${ }^{6,8-12}$ The high prevalence of poor or average SROH in this study may be an indication of a high burden of oral health problems and unmet treatment need in this population in Myanmar. ${ }^{5}$ This survey discovered that some proportion of participants $(6.5 \%)$ avoided visiting a dental care professional because of the costs in the past 12 months, despite having poorer SROH than those who did not avoid $(\mathrm{P}=0.037)$ (analysis not shown). Considering that most participants $(59.5 \%)$ consulted a private dental practice rather than a government dental clinic $(22.3 \%)$ in their last dental visit (analysis not shown), there should be consideration to make public dental health care services more accessible. Another possible reason for avoiding dental care is dental anxiety. ${ }^{41,42}$

In contrast to previous studies, ${ }^{6,13,15-17}$ this study did not find an association between sociodemographic risk factors and poor SROH. It is possible that such differences were not found because this urban study population was similar in terms of educational level and economic indicators. Consistent with previous studies, ${ }^{11,18-22}$ this study found that having various oral conditions (tooth loss, cavities, bleeding gums, and teeth that are sensitive to heat or cold), increased the risk for poor SROH. In bivariate analysis, this investigation found an association between having chronic conditions and poor SROH. This result was also identified in some previous investigations. ${ }^{20,28}$

While some previous investigations ${ }^{26,27}$ found a negative relationship between oral health knowledge and poor $\mathrm{SROH}$, this study found a positive relationship. "It is possible that in the epidemiological transition from infectious to non-communicable disease, $" 32$ residents in urban areas are more likely to adopt lifestyle changes, including poor oral health practices, such as a diet high in free sugars, tobacco use and poor oral hygiene, which in turn can negatively affect the oral health status. ${ }^{32}$ In bivariate analysis, poor tooth cleaning practices were associated with poor SROH. Inadequate tooth brushing and poor oral hygiene practices have also been found related to poor SROH in previous studies. ${ }^{11,15}$ Previous studies found a mixed results in relation to low or high dental attendance and poor SROH status, ${ }^{7,11,13,17,24,28,29}$ while this study, in agreement with some studies, ${ }^{17,24,29}$ found a strong positive relationship between dental attendance 
Table 2 Sample Characteristics And Bivariate Analysis Between Individual Risk Factors And Self-Rated Poor Oral Health

\begin{tabular}{|c|c|c|c|c|}
\hline \multirow[t]{2}{*}{ Variable } & & \multirow{2}{*}{$\begin{array}{l}\text { Sample } \\
\mathrm{N} \text { (\%) }\end{array}$} & \multirow{2}{*}{$\begin{array}{l}\begin{array}{l}\text { Self-Rated } \\
\text { Poor Oral Health }\end{array} \\
\mathrm{n}(\%)\end{array}$} & \multirow{2}{*}{$\begin{array}{l}\text { Chi-Square } \\
\text { P-value }\end{array}$} \\
\hline & & & & \\
\hline \multicolumn{5}{|l|}{ Sociodemographic variables } \\
\hline All & & 633 & $86(13.6)$ & \\
\hline Age & $\begin{array}{l}35-49 \text { years } \\
50-65 \text { years }\end{array}$ & $\begin{array}{l}435(68.7) \\
198(31.3)\end{array}$ & $\begin{array}{l}62(14.3) \\
24(12.1)\end{array}$ & 0.468 \\
\hline Sex & $\begin{array}{l}\text { Female } \\
\text { Male }\end{array}$ & $\begin{array}{l}285(45.0) \\
348(55.0)\end{array}$ & $\begin{array}{l}50(14.4) \\
36(12.6)\end{array}$ & 0.526 \\
\hline Education & $\begin{array}{l}<\text { Secondary } \\
\text { Secondary } \\
\text { Post-secondary }\end{array}$ & $\begin{array}{l}76(12.0) 311 \\
(49.1) \\
246(38.9)\end{array}$ & $\begin{array}{l}20(26.3) \\
31(10.0) \\
35(14.2)\end{array}$ & $<0.001$ \\
\hline Household income per month in Myanmar Kyats ${ }^{a}$ & $\begin{array}{l}\text { Low }(50,000-170,000) \\
\text { Medium }(171,000-299,000) \\
\text { High }(300,000 \text { and more) }\end{array}$ & $\begin{array}{l}211(33.3) \\
|6|(25.4) \\
26 \mid(4 I .2)\end{array}$ & $\begin{array}{ll}33 & (15.6) \\
21 & (13.0) \\
32 & (12.3)\end{array}$ & 0.553 \\
\hline \multicolumn{5}{|l|}{ Oral conditions } \\
\hline Number of teeth & $\begin{array}{l}\geq 20 \\
0-19\end{array}$ & $\begin{array}{l}563(88.9) \\
70(11.1)\end{array}$ & $\begin{array}{l}61(10.8) \\
25(35.7)\end{array}$ & $<0.001$ \\
\hline Cavities & $\begin{array}{l}0 \\
\text { I or more }\end{array}$ & $\begin{array}{l}328(51.8) \\
305(48.2)\end{array}$ & $\begin{array}{l}17(5.2) \\
69(22.6)\end{array}$ & $<0.001$ \\
\hline Dentures (removable) & $\begin{array}{l}\text { No } \\
\text { Yes }\end{array}$ & $\begin{array}{l}604(95.4) \\
29(4.6)\end{array}$ & $\begin{array}{l}75(12.4) \\
11(37.9)\end{array}$ & $<0.001$ \\
\hline Pain in teeth or mouth in the past 12 months & $\begin{array}{l}\text { No } \\
\text { Yes }\end{array}$ & $\begin{array}{l}46 \mid(72.8) \\
\mid 72(27.2)\end{array}$ & $\begin{array}{l}30(6.5) \\
56(32.6)\end{array}$ & $<0.001$ \\
\hline Bleeding gums when brushing in past month & $\begin{array}{l}\text { No } \\
\text { Yes }\end{array}$ & $\begin{array}{l}547(86.4) \\
86(13.6)\end{array}$ & $\begin{array}{l}56(10.2) \\
30(34.9)\end{array}$ & $<0.001$ \\
\hline Teeth sensitive to heat or cold in past month & $\begin{array}{l}\text { No } \\
\text { Yes }\end{array}$ & $\begin{array}{l}522(82.5) \\
\text { III }(17.5)\end{array}$ & $\begin{array}{l}50(9.6) \\
36(32.4)\end{array}$ & $<0.001$ \\
\hline Bad breath in past month & $\begin{array}{l}\text { No } \\
\text { Yes }\end{array}$ & $\begin{array}{l}621(98.1) \\
12(1.9)\end{array}$ & $\begin{array}{l}85(13.7) \\
\text { I (8.3) }\end{array}$ & 0.592 \\
\hline \multicolumn{5}{|l|}{ General health status } \\
\hline Chronic conditions & $\begin{array}{l}<\text { l or more } \\
\text { I or more }\end{array}$ & $\begin{array}{l}520(82.1) \\
113(17.9)\end{array}$ & $\begin{array}{l}60(11.5) \\
26(23.0)\end{array}$ & $<0.001$ \\
\hline Overweight or obesity & $\begin{array}{l}\text { No } \\
\text { Yes }\end{array}$ & $\begin{array}{l}46 \mid(72.8) \\
\mid 72(27.2)\end{array}$ & $\begin{array}{l}62(13.4) \\
24(14.0)\end{array}$ & 0.480 \\
\hline Depressive symptoms & $\begin{array}{l}\text { No } \\
\text { Yes }\end{array}$ & $\begin{array}{l}608(96.1) \\
25(3.9)\end{array}$ & $6(24.0)$ & 0.109 \\
\hline Sleep problem (moderate-extreme) & $\begin{array}{l}\text { No } \\
\text { Yes }\end{array}$ & $\begin{array}{l}562(88.8) \\
71 \text { (II.2) }\end{array}$ & $\begin{array}{l}73(13.0) \\
13(18.3)\end{array}$ & 0.149 \\
\hline \multicolumn{5}{|l|}{ Oral health knowledge and behaviour } \\
\hline Oral health knowledge & $\begin{array}{l}\text { Scores: } 0-3 \\
\text { Scores: } 4-8\end{array}$ & $\begin{array}{l}302(46.7) \\
331(52.3)\end{array}$ & $\begin{array}{l}28(9.3) \\
58(17.5)\end{array}$ & 0.002 \\
\hline
\end{tabular}


Table 2 (Continued).

\begin{tabular}{|c|c|c|c|c|}
\hline \multirow[t]{2}{*}{ Variable } & & Sample & $\begin{array}{l}\text { Self-Rated } \\
\text { Poor Oral Health }\end{array}$ & Chi-Square \\
\hline & & $\mathbf{N}(\%)$ & n (\%) & P-value \\
\hline Tooth cleaning & $\begin{array}{l}<\text { Twice a day } \\
\text { Twice or more/Day }\end{array}$ & $\begin{array}{l}266(42.0) \\
367(58.0)\end{array}$ & $\begin{array}{l}50(18.8) \\
36(9.8)\end{array}$ & $<0.001$ \\
\hline Uses toothpaste & $\begin{array}{l}\text { Without fluoride } \\
\text { With fluoride }\end{array}$ & $\begin{array}{l}100(15.8) \\
533(84.2)\end{array}$ & $\begin{array}{l}18(18.0) \\
68(12.8)\end{array}$ & 0.160 \\
\hline Saw dentist within the past 12 month & $\begin{array}{l}\text { No } \\
\text { Yes }\end{array}$ & $\begin{array}{l}555(87.7) \\
78(12.3)\end{array}$ & $\begin{array}{l}50(9.0) \\
36(46.2)\end{array}$ & $<0.001$ \\
\hline Soft drinks & $\begin{array}{l}<\text { Once/Day } \\
\geq \text { Once/Day }\end{array}$ & $\begin{array}{l}366(57.8) \\
267(42.2)\end{array}$ & $\begin{array}{l}44(12.0) \\
42(15.7)\end{array}$ & 0.179 \\
\hline \multicolumn{5}{|l|}{ General health behaviour } \\
\hline Current smoker & $\begin{array}{l}\text { No } \\
\text { Yes }\end{array}$ & $\begin{array}{l}480(75.8) \\
153(24.2)\end{array}$ & $\begin{array}{l}67(14.0) \\
19(12.4)\end{array}$ & 0.628 \\
\hline Current smokeless tobacco user & $\begin{array}{l}\text { No } \\
\text { Yes }\end{array}$ & $\begin{array}{l}493(77.9) \\
140(22.1)\end{array}$ & $\begin{array}{l}59(12.0) \\
27(19.3)\end{array}$ & 0.026 \\
\hline Problem drinking & $\begin{array}{l}\text { No } \\
\text { Yes }\end{array}$ & $\begin{array}{l}567(89.6) \\
66(10.4)\end{array}$ & $\begin{array}{l}76(13.4) \\
10(15.2)\end{array}$ & 0.406 \\
\hline Inadequate fruit and vegetable consumption & $\begin{array}{l}\text { No } \\
\text { Yes }\end{array}$ & $\begin{array}{l}124(19.6) \\
509(80.4)\end{array}$ & $\begin{array}{l}18(14.5) \\
68(13.4)\end{array}$ & 0.416 \\
\hline Skipping breakfast & $\begin{array}{l}\text { No } \\
\text { Yes }\end{array}$ & $\begin{array}{l}481(76.0) \\
152(24.0)\end{array}$ & $\begin{array}{l}47(9.8) \\
39(25.7)\end{array}$ & $<0.001$ \\
\hline
\end{tabular}

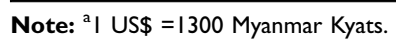

Table 3 Descriptives Of Oral Health Status By Gender And Age Group

\begin{tabular}{|c|c|c|c|c|c|c|c|}
\hline \multirow[t]{2}{*}{ Oral Health Status Questions } & All & Men & Women & P-value & 35-49 Years & 50-65 Years & \multirow[t]{2}{*}{ P-value } \\
\hline & $\mathbf{N}(\%)$ & $\mathbf{N}(\%)$ & $\mathbf{N}(\%)$ & & $\mathbf{N}(\%)$ & $\mathbf{N}(\%)$ & \\
\hline \multicolumn{8}{|c|}{ How would you describe the state of your teeth? } \\
\hline $\begin{array}{l}\text { Excellent } \\
\text { Very good } \\
\text { Good } \\
\text { Average } \\
\text { Poor } \\
\text { Very poor }\end{array}$ & $\begin{array}{l}\text { I }(0.2) \\
29(4.6) \\
\text { I54 (24.3) } \\
367(58.0) \\
80(12.6) \\
2(0.3)\end{array}$ & $\begin{array}{l}0(0.0) \\
22(6.3) \\
94(27.0) \\
183(52.6) \\
48(13.8) \\
I(0.3)\end{array}$ & $\begin{array}{l}\text { I }(0.4) \\
7(2.5) \\
60(2 I .1) \\
\text { I } 84(64.6) \\
32(11.2) \\
I(0.4)\end{array}$ & 0.020 & $\begin{array}{l}\text { I }(0.2) \\
27(6.2) \\
96(22.1) \\
252(57.9) \\
58(13.3) \\
I(0.2)\end{array}$ & $\begin{array}{l}0(0.0) \\
2(1.0) \\
58(29.3) \\
115(58.1) \\
22(I I .1) \\
I(0.5)\end{array}$ & 0.031 \\
\hline \multicolumn{8}{|c|}{ How would you describe the state of your gums? } \\
\hline $\begin{array}{l}\text { Excellent } \\
\text { Very good } \\
\text { Good } \\
\text { Average } \\
\text { Poor } \\
\text { Very poor }\end{array}$ & $\begin{array}{l}6(0.9) \\
25(3.9) \\
197(31.1) \\
360(56.9) \\
45(7.1) \\
0(0.0)\end{array}$ & $\begin{array}{l}5(1.4) \\
12(3.4) \\
123(35.3) \\
181(52.0) \\
27(7.8) \\
0(0.0)\end{array}$ & $\begin{array}{l}\text { I }(0.4) \\
\text { I } 3(4.6) \\
74(26.0) \\
\text { I } 79(62.8) \\
\text { I } 8(6.3) \\
0(0.0)\end{array}$ & 0.032 & $\begin{array}{l}6(1.4) \\
22(5.1) \\
128(29.4) \\
246(56.6) \\
33(7.6) \\
0(0.0)\end{array}$ & $\begin{array}{l}0(0.0) \\
3(1.3) \\
69(34.8) \\
114(57.6) \\
12(6.1) \\
0(0.0)\end{array}$ & 0.066 \\
\hline
\end{tabular}

and poor SROH status. The possible reason for the correlation between dental attendance and poor $\mathrm{SROH}$ status, may be related to the fact that the majority (91.9\%) among those who had seen a dentist did consult because of "pain or trouble with teeth, gums and mouth and only $8.1 \%$ had gone for a preventative check-up (analysis not shown)". 32 
Table 4 Associations With Poor Self-Rated Oral Health Status Determined By Multivariable Logistic Regression

\begin{tabular}{|c|c|c|}
\hline Variables & $\operatorname{AOR}(95 \% \mathrm{Cl})^{\mathrm{a}, \mathrm{b}}$ & P-value \\
\hline \multicolumn{3}{|l|}{ Sociodemographic variables } \\
\hline \multicolumn{3}{|l|}{ Age } \\
\hline $35-49$ years & (Reference) & 0.516 \\
\hline $50-65$ years & $0.78(0.37,1.65)$ & \\
\hline \multicolumn{3}{|l|}{ Sex } \\
\hline Female & (Reference) & 0.491 \\
\hline Male & $1.30(0.62,2.74)$ & \\
\hline \multicolumn{3}{|l|}{ Education } \\
\hline$<$ Post-secondary & (Reference) & 0.035 \\
\hline Post-secondary & $2.34(1.32,13.34)$ & \\
\hline \multicolumn{3}{|l|}{ Household income/month } \\
\hline Low & I (Reference) & 0.879 \\
\hline Medium & $1.07(0.45,2.53)$ & 0.192 \\
\hline High & $0.59(0.27,1.31)$ & \\
\hline \multicolumn{3}{|l|}{ General health status } \\
\hline Chronic conditions (I or more) & $1.23(0.57,2.64)$ & 0.593 \\
\hline Overweight or obesity & $0.92(0.45,1.91)$ & 0.825 \\
\hline Depressive symptoms (yes) (base $=$ no) & $2.58(0.59,11.30)$ & 0.208 \\
\hline Sleep problem (moderate-extreme) & $0.63(0.24,1.66)$ & 0.344 \\
\hline \multicolumn{3}{|l|}{ Oral conditions } \\
\hline Number of teeth $(0-19)$ (base $=20$ or more) & $5.67(2.40,13.39)$ & $<0.001$ \\
\hline Cavity (I or more) (base=none) & $4.35(1.95,9.72)$ & $<0.001$ \\
\hline Dentures (removable) (base=none) & $4.35(1.32,14.34)$ & 0.016 \\
\hline Pain in teeth or mouth in the past 12 months & $1.38(0.64,2.95)$ & 0.413 \\
\hline Bleeding gums when brushing in past month & $4.56(1.79,11.60)$ & $<0.001$ \\
\hline Teeth sensitive to heat or cold in past month & $4.25(1.87,9.64)$ & $<0.001$ \\
\hline Bad breath in past month & $0.62(0.05,8.02)$ & 0.715 \\
\hline \multicolumn{3}{|l|}{ Oral knowledge and health behaviour } \\
\hline Oral health knowledge (scores 4-8) (base: scores 0-3) & $2.83(1.395 .77)$ & 0.004 \\
\hline Tooth cleaning (twice or more/day) (base:<twice/day) & $0.70(0.36,1.36)$ & 0.290 \\
\hline Uses toothpaste with fluoride & $0.58(0.26,1.27)$ & 0.170 \\
\hline Soft drinks ( $\geq$ once/day) (base:<once/day) & I.47 $(0.77,2.83)$ & 0.246 \\
\hline Dental care visit within past 12 months (base $=$ more than one year or never) & $3.78(1.78,8.06)$ & $<0.001$ \\
\hline \multicolumn{3}{|l|}{ General health behaviour } \\
\hline Current smoker & $0.47(0.20,1.13)$ & 0.092 \\
\hline Smokeless tobacco use & $1.23(0.5 \mathrm{I}, 2.94)$ & 0.651 \\
\hline Problem drinking & $2.87(0.86,9.64)$ & 0.087 \\
\hline Inadequate fruit and vegetable consumption & $0.85(0.39,1.83)$ & 0.669 \\
\hline Skipping breakfast & $4.23(1.96,9.09)$ & $<0.001$ \\
\hline
\end{tabular}

Notes: ${ }^{a}$ Adjusted for all variables in the table; ${ }^{b}$ Hosmer and Lemeshow Test: Chi-square $=18.88, P=0.044$; Nagelkerke ${ }^{2}=0.48$. Abbreviations: AOR, Adjusted Odds Ratio; $\mathrm{Cl}$, Confidence Interval.

A number of studies ${ }^{6,11,17,30}$ found an association between smoking and poor SROH, while in this study only in bivariate analysis an association between current smokeless tobacco use and poor SROH was found. Some studies $^{30,31}$ found an association between poor dietary behaviour and poor $\mathrm{SROH}$, while this study found a strong 
association between skipping breakfast and poor SROH. A previous study found a clustering pattern of oral and general health-risk behaviours, e.g., current smoking, less frequent tooth brushing, skipping breakfast, current alcohol use, high intake of sugar and no dental visits. ${ }^{43}$

\section{Study Limitations}

The study design was limited to the cross-sectional nature, the small geographic location (three wards in one district), and the use of only self-reported measures. For example, self-reported cavities may underestimate "the prevalence of dental caries by $9.3 \%$ in comparison to clinical evaluations but is valid for population-based health surveys with the aim of planning and monitoring oral health actions." 44 In investigations in the future oral examinations should be conducted, in addition to self-reported measures.

\section{Conclusion}

A high proportion of poor or average $\mathrm{SROH}$ status was found and several risk factors (various oral conditions, oral health knowledge, dental care attendance, and skipping breakfast) were identified that can help in guiding oral health care programming in Myanmar.

\section{Acknowledgement}

The China Medical Board (CMB) is thanked for supporting the study.

\section{Disclosure}

The authors declare that they have no competing interest.

\section{References}

1. Petersen PE, Bourgeois D, Ogawa H, Estupinan-Day S, Ndiaye C. The global burden of oral diseases and risks to oral health. Bull World Health Organ. 2005;83(9):661-669.

2. Perera I, Ekanayake L. Factors influencing perception of oral health among adolescents in Sri Lanka. Int Dent J. 2008;58:349-355.

3. Blizniuk A, Ueno M, Zaitsu T, Kawaguchi Y. Association between self-reported and clinical oral health status in Belarusian adults. $J$ Investig Clin Dent. 2017;8:2. doi:10.1111/jicd.12206

4. Peltzer K, Pengpid S. Dental health status and oral health behavior among university students from five ASEAN countries. Nagoya J Med Sci. 2017;79:123-133. doi:10.18999/nagjms.79.2.123

5. Aung EE, Maung K, Zaitsu T, Kawaguchi Y. An overview of oral health situation and challenges in Myanmar. AJRMMS. 2018;1(1):110. Article no.AJRMMS.65.

6. Mejia G, Armfield JM, Jamieson LM. Self-rated oral health and oral health-related factors: the role of social inequality. Aust Dent J. 2014;59(2):226-233. doi:10.1111/adj.12173

7. Vale EB, Mendes Ada C, Moreira Rda S. Self-perceived oral health among adults in Northeastern Brazil. Rev Saude Publica. 2013;47 (Suppl 3):98-108. doi:10.1590/s0034-8910.2013047004893
8. Pengpid S, Peltzer K. Self-rated oral health status and social and health determinants among community dwelling adults in Kenya. Afr $J$ Health Sci. in press.

9. Olusile AO, Adeniyi AA, Orebanjo O. Self-rated oral health status, oral health service utilization, and oral hygiene practices among adult Nigerians. BMC Oral Health. 2014;14:140. doi:10.1186/1472-683114-140

10. Cheema S, Maisonneuve $\mathrm{P}, \mathrm{Al}-\mathrm{Thani} \mathrm{MH}$, et al. Oral health behavior and factors associated with poor oral status in Qatar: results from a national health survey. J Public Health Dent. 2017;77(4):308-316. doi:10.1111/jphd.12209

11. Olutola BG, Ayo-Yusuf OA. Socio-environmental factors associated with self-rated oral health in South Africa: a multilevel effects model. Int J Environ Res Public Health. 2012;9(10):3465-3483. doi:10.3390/ijerph9103465

12. Hakeberg M, Wide Boman U. Self-reported oral and general health in relation to socioeconomic position. BMC Public Health. 2017;18 (1):63. doi:10.1186/s12889-017-4609-9

13. Peker K. The Determinants of Self-Rated Oral Health in Istanbul Adults (pp. 171-188), Oral Health Care - Pediatric, Research, Epidemiology and Clinical Practices. Virdi M, Editor. InTech; 2012. ISBN: 978-953-51-0133-8. Available from: http://www.intecho pen.com/books/oral-health-care-pediatric-research-epidemiologyandclinical-practices/the-determinants-of-self-rated-oral-health-in-istan bul-adults. Accessed October 10, 2019.

14. Morin NM, Dye BA, Hooper TI. Influence of cigarette smoking on the overall perception of dental health among adults aged 20-79 years, United States, 1988-1994. Public Health Rep. 2005;120 (2):124-132. doi:10.1177/003335490512000205

15. Nico LS, Andrade SS, Malta DC, Pucca Júnior GA, Peres MA. Selfreported oral health in the Brazilian adult population: results of the 2013 National Health Survey. Cien Saude Colet. 2016;21(2):389398. doi:10.1590/1413-81232015212.25942015

16. Kwon M-H, Choi H-S. Association of gender, education, income and selfperceived oral health status among the Koreans; The 6th Korea National Health and Nutrition Examination Survey (KNHANES). Indian J Sci \& Technol. 2016;9(41). doi:10.17485/ijst/2016/v9i41/103895

17. Cárdenas-Bahena Á, Velázquez-Olmedo LB, Falcón-Flores JA, et al. Self-perception of oral health in older adults from Mexico City. Rev Med Inst Mex Seguro Soc. 2018;56(Suppl 1):S54-S63.

18. Jones JA, Kressin NR, Spiro A 3rd, et al. Self-reported and clinical oral health in users of VA health care. J Gerontol A Biol Sci Med Sci. 2001;56(1):M55-M62.

19. Singh A, Purohit BM. Exploring patient satisfaction levels, self-rated oral health status and associated variables among citizens covered for dental insurance through a National Social Security Scheme in India. Int Dent J. 2017;67(3):172-179. doi:10.1111/idj.12285

20. Arantes R, Frazão P. Subjective oral symptoms associated with selfrated oral health among Indigenous groups in Central-West Brazil. Community Dent Oral Epidemiol. 2018;46:352-359. doi:10.1111/ cdoe. 12375

21. Pattussi MP, Peres KG, Boing AF, Peres MA, Da Costa JS. Self-rated oral health and associated factors in Brazilian elders. Community Dent Oral Epidemiol. 2010;38(4):348-359. doi:10.1111/j.16000528.2010.00542.x

22. Ekbäck G, Näslund I, Montgomery SM, Ordell S. Self-perceived oral health and obesity among 65 years old in two Swedish counties. Swed Dent J. 2010;34(4):207-215.

23. Amarasena N, Kapellas K, Brown A, et al. Psychological distress and self-rated oral health among a convenience sample of Indigenous Australians. J Public Health Dent. 2015;75(2):126-133. doi:10.1111/ jphd. 12080

24. Andrade FB, Lebrão ML, Santos JL, Duarte YA, Teixeira DS. Factors related to poor self-perceived oral health among community-dwelling elderly individuals in São Paulo, Brazil. Cad Saude Publica. 2012;28 (10):1965-1975. doi:10.1590/s0102-311x2012001000014 
25. Dumitrescu AL, Toma C, Lascu V. Associations among sleep disturbance, vitality, fatigue and oral health. Oral Health Prev Dent. 2010;8(4):323-330.

26. Naghibi Sistani MM, Yazdani R, Virtanen J, Pakdaman A, Murtomaa H. Determinants of oral health: does oral health literacy matter? ISRN Dent. 2013;2013:249591. doi:10.1155/2013/249591

27. Jones K, Parker EJ, Jamieson LM. Access, literacy and behavioural correlates of poor self-rated oral health amongst an indigenous south Australian population. Community Dent Health. 2014;31(3):167-171.

28. Afonso-Souza G, Nadanovsky P, Chor D, Faerstein E, Werneck GL, Lopes CS. Association between routine visits for dental checkup and self-perceived oral health in an adult population in Rio de Janeiro: the Pró-Saúde Study. Community Dent Oral Epidemiol. 2007;35(5):393400. doi:10.1111/j.1600-0528.2006.00343.x

29. Armfield JM, Mejía GC, Jamieson LM. Socioeconomic and psychosocial correlates of oral health. Int Dent J. 2013;63(4):202-209. doi:10.1111/idj.12032

30. Liu Y. The relationship between lifestyle and self-reported oral health among American adults. Int Dent J. 2014;64(1):46-51. doi:10.1111/ idj.12061

31. Quandt SA, Chen H, Bell RA, et al. Food avoidance and food modification practices of older rural adults: association with oral health status and implications for service provision. Gerontologist. 2010;50(1):100-111. doi:10.1093/geront/gnp096

32. Htun KCSS, Peltzer K. Oral health-related quality of life among community dwelling middle-aged and older adults in an urban area in Magway region, Myanmar. Nagoya J Med Sci. 2019;81(1):103112. doi:10.18999/nagjms.81.1.103

33. World Health Organization (WHO) The STEPS instrument and support materials, 2014. Available from: http://www.who.int/ncds/surveil lance/steps/instrument/en/. Accessed May 10, 2016.

34. Wen CP, David Cheng TY, Tsai SP, et al. Are Asians at greater mortality risks for being overweight than Caucasians? Redefining obesity for Asians. Public Health Nutr. 2009;12:497-506. doi:10.1017/S13689 80008002802

35. Kroenke K, Spitzer RL, Williams JB. The PHQ-9: validity of a brief depression severity measure. J Gen Intern Med. 2001;16(9):606-613. doi:10.1046/j.1525-1497.2001.016009606.x
36. Lotrakul M, Sumrithe S, Saipanish R. Reliability and validity of the Thai version of the PHQ-9. BMC Psychiatry. 2008;8:46. doi:10.1186/ 1471-244X-8-46

37. Stranges S, Tigbe W, Gómez-Olivé FX, Thorogood M, Kandala NB. Sleep problems: an emerging global epidemic? Findings from the INDEPTH WHO-SAGE study among more than 40,000 older adults from 8 countries across Africa and Asia. Sleep. 2012;35:1173-1181. doi:10.5665/sleep. 2012

38. Naghibi Sistani MM, Montazeri A, Murtomaa YR. New oral health literacy instrument for public health: development and pilot testing. $J$ Investig Clin Dent. 2014;5(4):313-321. doi:10.1111/jicd.12042

39. Bush K, Kivlahan DR, McDonell MB, Fihn SD, Bradley KA. The AUDIT alcohol consumption questions (AUDIT-C): an effective brief screening test for problem drinking. Ambulatory Care Quality Improvement Project (ACQUIP). Alcohol use disorders identification test. Arch Intern Med. 1998;158(16):1789-1795.

40. Satheannoppakao W, Aekplakorn W, Pradipasen M. Fruit and vegetable consumption and its recommended intake associated with sociodemographic factors: Thailand National Health Examination Survey III. Public Health Nutr. 2009;12(11):2192-2198. doi:10.1017/S1368 980009005837

41. Hakeberg M, Wide Boman U. Dental care attendance and refrainment from dental care among adults. Acta Odontol Scand. 2017;75(5):366371. doi:10.1080/00016357.2017.1317105

42. Appukuttan D, Subramanian S, Tadepalli A, Damodaran LK. Dental anxiety among adults: an epidemiological study in South India. $N \mathrm{Am}$ $J$ Med Sci. 2015;7(1):13-18. doi:10.4103/1947-2714.150082

43. Jordão LMR, Malta DC, Freire MDCM. Clustering patterns of oral and general health-risk behaviours in Brazilian adolescents: findings from a national survey. Community Dent Oral Epidemiol. 2018;46 (2):194-202. doi:10.1111/cdoe.12354

44. Silva AE, Menezes AM, Assunção MC, et al. Validation of selfreported information on dental caries in a birthcohort at 18 years of age. PLOS ONE. 2014;9(9):e106382. doi:10.1371/journal.pone. 0106382 eCollection 2014.
Clinical, Cosmetic and Investigational Dentistry

\section{Publish your work in this journal}

Clinical, Cosmetic and Investigational Dentistry is an international, peer-reviewed, open access, online journal focusing on the latest clinical and experimental research in dentistry with specific emphasis on cosmetic interventions. Innovative developments in dental materials, techniques and devices that improve outcomes and patient

\section{Dovepress}

satisfaction and preference will be highlighted. The manuscrip management system is completely online and includes a very quick and fair peer-review system, which is all easy to use. Visit http://www.dovepress.com/testimonials.php to read real quotes from published authors.

Submit your manuscript here: https://www.dovepress.com/clinical-cosmetic-and-investigational-dentistry-journal 